\title{
The effect of grain type and processing on equine chewing time
}

\author{
Christine Brøkner' ${ }^{7}$ Peder Nørgaard' and Tine Mangart Søland² \\ Department of Basic Animal and Veterinary Sciences' and Department of Large Animal Sciences², KVL, Frederiksberg, Denmark
}

\begin{abstract}
Summary
An experiment was conducted to study the hypothesis that increased grain NDF and feed particle size result in increased chewing time in horse. Three adult Standardbred horses (Group I) and 3 adult Icelandic horses (Group II) were fed 3 daily meals during 3 consecutive days in two $3 \times 3$ completely randomized block design experiments. Meals of (Group I: $1.0 \mathrm{~kg}$ and Group II: $0.5 \mathrm{~kg}$ ) oats, barley and wheat were fed whole, rolled and ground at $10 \mathrm{am}, 12 \mathrm{pm}, 2 \mathrm{pm}$. Chewing activity was measured using a special chewing halter. The basic chewing rate is estimated as jaw movements (JM) per min. Efficient chewing time (EPTIME) in min per kg DM is chewing time corrected for pauses. Regularity of JM is standard deviation of time intervals between individual JM. Faecal particle size was analysed using sieving technique and image analysis. The mean EPTIME was 22 and $15 \mathrm{~min} / \mathrm{kg}$ DM grain $(\mathrm{P}<0.01)$ for Icelandic and Standardbred horses, respectively. The basic chewing rate, chewing regularity and faecal particle size did not differ between horses. The EPTIME for whole grain was $18 \mathrm{~min} / \mathrm{kg}$ DM but not systematically shorter than for ground grain $(20 \mathrm{~min} / \mathrm{kg} \mathrm{DM})$. EPTIME for oats was $21 \mathrm{~min} / \mathrm{kg}$ DM but not significantly longer than wheat (18 min/kg DM). Jaw movements were systematically more regular during intake of whole grain as compared to ground grain $(\mathrm{P}<0.01)$. In conclusion, the presumed hypothesis could not be accepted. The achieved results indicate that regularity of jaw movements during eating provide a new method for quantifying cereal grain characteristics. The achieved results indicate that regularity of jaw movements during eating provide a new biological method for quantifying cereal grain characteristics.
\end{abstract}

Keywords: chewing, grain characteristics, NDF, Icelandic horse, Standardbred, faecal, particle size

\begin{abstract}
Auswirkung von Getreideart und -verarbeitung auf die Kauzeit beim Pferd
Die Hypothese des Experiments war, dass höhere NDF-Gehalte in Getreide und gröbere Vermahlung beim Pferd in einer längeren Kauzeit resultieren. Drei erwachsene Traberpferde (Gruppe I) und drei erwachsene Islandpferde (Gruppe II) wurden drei Mal täglich, während drei aufeinander folgenden Tagen gefüttert. Des Experiment wurde als 3 × 3 Block-Design organisiert. Die Mahlzeit (Gruppe I: 1.0 kg und Gruppe II: $0.5 \mathrm{~kg}$ ) bestand aus Hafer, Gerste und Weizen. Es wurde als ganzes, walzenförmig und gemahlen um 10 Uhr, 12 Uhr und 14 Uhr verabreicht. Die Kauaktivität wurde mit einem speziellen Halfter gemessen. Die Standardkaufrequenz ist angegeben als (JM) pro Minute. Die effektive Kauzeit (EPTIME) in Minuten pro kg TS ist die Kauzeit berichtigt um die Pausen. Die Gleichmäßigkeit des JM ist die Standardabweichung von Zeitintervallen zwischen den einzelnen JM. Die Größe der Kotpartikel wurde analysiert unter Anwendung der Siebtechnik und Bildanalyse. Der Mittelwert des EPTIME war zwischen 22 und $15 \mathrm{~min} / \mathrm{kg}$ TS Korn $(\mathrm{P}<0.01)$ für Islandpferde beziehungsweise Traber. Die Standardkaufrequenz, die Gleichmäßigkeit des JM und die Größe der Kotpartikel waren nicht verschieden zwischen den Pferden. Die EPTIME für ganze Körner war $18 \mathrm{~min} / \mathrm{kg}$ TS. Sie war nicht systematisch langsamer als für gemahlene Körner (20 min/kg TS). Die EPTIME für Hafer war $21 \mathrm{~min} / \mathrm{kg}$ TS. Sie war nicht signifikant schneller als Weizen (18 min/kg TS). Die JM war systematisch gleichmäßiger, wenn die Pferde ganze Körner fraßen als gemahlene Körner $(\mathrm{P}<0.01)$. Die angenommene Hypothese wurde nicht bestätigt.
\end{abstract}

Schlüsselwörter: Kaven, Korncharakteristik, NDF, Islandpferd, Traberpferd, Mist, Partikelgröße

\section{Introduction}

Recordings and qualitative estimations of equine chewing activity when fed different processed oats have previously been estimated by use of both visual observation and telemetrically recordings (Meyer et al. 1975). A new digital recording method now makes it possible to quantitatively evaluate chewing activity in horses (Nørgaard et al. 2004). The diet of domesticated horses primarily includes 0 - $75 \%$ (of total DM) commercial concentrate, coarsely processed grains and a daily minimum intake of $1 \mathrm{~kg}$ structural fibres per 100 $\mathrm{kg}$ live weight (Meyer 1995, Zeyner et al., 2004). However, a diet consisting of roughage and concentrate is typically eaten in less than 4 hours (Argo et al. 2002) as opposed to free ranged horses, which spend up to $12 \mathrm{~h}$ daily eating grasses, legumes and shrubs (Heleski et al. 2002, Ralston 1984).
According to Van Soest (1994) the dietary content of structural fibres can be quantified by NDF, which range from $9 \%$ in wheat grain to $66 \%$ in barley straw (of \% DM) (NRC, 1989). It is well documented that NDF intake and processing affect the overall chewing time in ruminants (Mertens, 1994); therefore, the content of structural fibre of cereal grains and forages of different physical forms have been ranked by use of a chewing index value (Balch 1971). Sufficient intake of structural fibre in dairy cows can be obtained by a minimum chewing index value of $30 \mathrm{~min} / \mathrm{kg}$ DM (Kristensen and Nørgaard 1987).

Raff and Jorgensen (2003) observed that horses chew 70 to 90 min per kg unchopped forage NDF. Oats contain roughly 3 times more NDF than wheat (NRC 1989). Knowing the effect of forage NDF content on equine chewing time and 
feed processing on chewing time in ruminants makes it interesting to measure the effect of cereal grain characteristics on chewing time in horses. In the future, quantifying cereal grain characteristics can contribute to formulate equine diets that stimulate feed intake and chewing activity.

According to Meyer et al. (1975) ponies spent 3-4 times longer consuming a certain amount of feed as compared to horses. Horses only masticate feeds once during eating; therefore, hypothetically the faecal particle distribution can be used as an indicator of feed particle size reduction during eating (Nørgaard 2003).

We hypothesise that increased grain NDF content and feed particle size increase mean chewing time. The aim of the present study is to measure chewing time, basic chewing rate, chewing regularity, faecal particle size distribution and the proportion of whole grain appearing in faeces in two different horse breeds.

\section{Materials and Methods}

Experimental design

Three adult Standardbred horses (Group I, horses no. 101 103) and 3 Icelandic horses (Group II, horses no. 104-106) were fed 3 daily grain meals during 3 consecutive days in a $3 \times 3$ completely randomized block design experiment, see Table 1. The grain meals included wheat, barley and oat, which were fed whole, rolled or ground at $10.00 \mathrm{am}, 12.00$ am and $2.00 \mathrm{pm}$. In addition, the horses were fed commercial concentrate feeds: muesli or feed pills at 8 am and 4 pm, randomized. The horses had free access to straw from 10.30 am to $11.00 \mathrm{am}$, and from $4.15 \mathrm{pm}$ to $7.30 \mathrm{am}$ the next morning. Sampling Group II is repeated after three days break. The same feeding schedule is maintained during the break.

\section{Animals}

This research complied with the guidelines of the Danish Ministry of justice (Act no. 726, 1993) with respect to animal experimentation and care of animals under study. The horses were housed under the same conditions in individually $4 \times 4$ $\mathrm{m}$ stalls on shavings. The horses in Group I had a mean weight of $530 \pm 42 \mathrm{~kg}$ and $370 \pm 7 \mathrm{~kg}$ in Group II. All horses were daily in the morning let out for $90 \mathrm{~min}$ in groups in paddocks without grass. The teeth of the horses were floated prior to the beginning of the experiment and the horses had a body condition score of 4 (Pagen 1998).

\section{Feeds}

The grains were cold processed in a President roller (rolled) or through a $2 \mathrm{~mm}$ screen using a Jesma hammer mill (ground). Commercial concentrates, muesli (Horse Muesli Kraft, a loose chaff based concentrate) and feed pills (TM Raket, $3 \mathrm{~mm}$ ) were produced by Tjoernehoej Moelle, Denmark using an ITAL Meccanica mixer (muesli) and a SpoutMatador system (feed pills). The horses were fed according to Danish standards for horses at maintenance level. The meal sizes for both groups are listed in Table 2. Refused grain was removed and weighted. Refused barley straw after the 10.30 am meals was removed, weighed and left in front of the horses for the night. The horses had constant access to fresh water. Seven days prior to the experiments the horses were adapted to the feeds.

\section{Feed analysis}

Feed samples were stored at $-20^{\circ} \mathrm{C}$ until analysis. Dry matter content was determined on the original, unprocessed feed samples at $105^{\circ} \mathrm{C}$ for $24 \mathrm{~h}$. The dried feed samples were ground through a $2 \mathrm{~mm}$ screen in a cutting mill. Nitrogen was measured according to the Kieldahl method. Crude fat content was analysed according to Stoldt (1952). The samples were first hydrolyzed in HCL followed by petroleum ether extraction. Crude fibre, NDF, ADF and lignin were analyzed according to Van Soest (1994) including amylase treatment and by use of Fibre-Bag system, FOSS Tecator $A B$, SE-263 21 Höganäs, Sweden (2001). Prior to the analysis the samples were defatted with acetone. After hot extraction with acid and de-fatting with acetone the samples were dried for $5 \mathrm{~h}$ at $105^{\circ} \mathrm{C}$. Double determination was performed and the obtained mean values from the chemical analyses are listed in Table 3.

Table 1 The feeding schedule of horses in the two groups. Der Futterplan die Pferden in der zwei Gruppen.

\begin{tabular}{|c|c|c|c|c|c|c|c|c|c|}
\hline \multicolumn{10}{|c|}{ Day } \\
\hline & \multicolumn{3}{|c|}{1} & \multicolumn{3}{|c|}{2} & \multicolumn{3}{|c|}{3} \\
\hline & 101 & 102 & 103 & 101 & 102 & 103 & 101 & 102 & 103 \\
\hline Time & 104 & 105 & 106 & 104 & 105 & 106 & 104 & 105 & 106 \\
\hline 8.00 & Muesli & Feed pills & Muesli & Feed pills & Muesli & Feed pills & Muesli & Feed pills & Muesli \\
\hline 10.00 & W Barley & G Wheat & R Oat & R Wheat & W Oat & G Barley & G Oat & R Barley & W Wheat \\
\hline 10.30 & Straw & Straw & Straw & Straw & Straw & Straw & Straw & Straw & Straw \\
\hline 12.00 & G Wheat & R Oat & W Barley & W Oat & G Barley & R Wheat & R Barley & W Wheat & G Oat \\
\hline 2.00 & R Oat & W Barley & G Wheat & G Barley & R Wheat & W Oat & W Wheat & G Oat & R Barley \\
\hline 4.00 & Feed pills & Muesli & Feed pills & Muesli & Feed pills & Muesli & Feed pills & Muesli & Feed pills \\
\hline
\end{tabular}

W: Whole; R: Rolled; G: Ground 
Table 2 Daily amount of feed $(\mathrm{kg})$ fed to horses of each group. Die Tägliche Futtermänge $(\mathrm{kg})$ abgefüttert zum Pferden in jede Gruppe.

\begin{tabular}{lcc}
\hline \multicolumn{1}{c}{ Feed } & Group I & Group II \\
\hline Muesli & 0.5 & 0.25 \\
Feed pills & 0.5 & 0.25 \\
Oats & 1.0 & 0.5 \\
Wheat & 1.0 & 0.5 \\
Barley & 1.0 & 0.5 \\
Barley straw & 5.5 & 4.0 \\
\hline
\end{tabular}

\section{Sampling chewing activity}

Time spend eating was visually observed. Chewing activity was recorded using a special chewing halter containing a water filled rubber tube placed ventral to the mouth and transverse the rostrocaudal plane of the head. Jaw movements affected the water pressure, which was recorded by a pressure transducer (Druck PDCR 10/D) and sampled at 12 $\mathrm{Hz}$ by a data logger placed on the back of the horse.

Individual chewing variables were estimated as described by Schleisner et al. (1999). The individual JM were identified from pressure oscillations and clustered by use of SAS (version 8.2, 1999) into eating cycles. The basic chewing rate (PBCR) was estimated within individual cycles (JM/min). The efficient chewing time (min, EPTIME) was the estimated duration of individual eating cycles corrected for pauses. Effective chewing rate (PECR) is the estimated number of recorded $\mathrm{JM} / \mathrm{min}$ within individual eating cycles. Regularity of JM (SPDDT) was characterised by standard deviation of time intervals between individual JM within each eating cycle. The estimations and plots of JM patterns were performed by use of SAS (version 8.2, 1999).

\section{Measurements of faecal particle dimensions}

A sample of $900 \mathrm{~g}$ faeces was daily collected from the floor during 3 days. The samples were mixed by stirring to make a total faeces sample. DM content was determined as described above. A total of $30 \mathrm{~g}$ faeces were placed in 3 individual nylon bags (pore size $40 \mu \mathrm{m}$ ) including $0.25 \mathrm{ml}$ liquid detergent per $\mathrm{g}$ faeces. The bags were machine-washed for $2 \mathrm{~h}$ at $40^{\circ} \mathrm{C}$ under constant agitation and the retained particles were freeze dried afterwards. The particles were sieved through 3 sieves with descending screen size pores of $2.56 \mathrm{~mm}, 1.0 \mathrm{~mm}, 0.5$ $\mathrm{mm}$ and the smallest particles were collected in the bottom bowl. Sub samples of particles from each sieve fraction were scanned at 300 to $2400 \mathrm{dpi}$. The individual particles were identified and their area, length and width were measured by use of image analysis. The arithmetic mean, median and 95 percentile values were estimated and the particle size distributions were plotted by use of SAS (version 8.2, 1999) as described by Nørgaard et al. (2004).

Sampling whole grain in faeces

A complete collection of faeces in Group II was sampled from the floor starting at $24 \mathrm{~h}$ after the first grain meal on day 1 and ended $96 \mathrm{~h}$ later. The samples were kept separately and frozen at $-20^{\circ} \mathrm{C}$. Whole grains in each individual faeces sample were separated out by means of wet sieving. Two sieves were placed on top of each other with descending screen size pores of $2.56 \mathrm{~mm}$ and $1.0 \mathrm{~mm}$ (Endecotts Limited, London, England). After separation the grains were dried as described above and separated into individual grain types, weighted and counted. The horses were not fed whole grains 3 days prior to the beginning of the experiment.

\section{Statistics}

The results of the two sampling periods for Group II were analysed using a t-test and were not systematically different; therefore, the results were pooled. The different response variables for chewing activity were evaluated by analysis of variance for a complete randomized block design, the model was unbalanced. The variances were assumed to be the same. The data were analysed using PROC MIXED procedure of SAS (version 8.2, 1999). The analysis was based on removing non-significant terms at a time from the full model until only significant terms remained in the final model. A Pvalue less than 0.05 were considered significant. The final model used was: $y i j k l=\mu+\alpha i+\beta i+\gamma k+\kappa l+\varepsilon i j k l$, where $y$ is response variable (i.e. chewing activity), $\alpha$ is Group, $\beta$ is form, $\kappa$ is grain, $\gamma$ is horses included in the model as random effect, $\varepsilon$ is residuals; $i=1,2 ; i=1,2,3 ; k=1,2,3$ the number of observations per i'th Group; $\mid=1,2,3$.

\section{Results}

Chewing activity

Jaw movements before, during and after a meal of whole barley (A) and ground oat (B) represent an eating cycle and is

Table 3 The chemical composition of feeds in \% of dry matter. Der Nährgehalt im Futter in \% TS.

\begin{tabular}{|c|c|c|c|c|c|c|}
\hline & Barley straw & Muesli & Feed pills & Oat & Wheat & Barley \\
\hline DM \% & 92 & 87 & 90 & 89 & 88 & 88 \\
\hline Ash & 7 & 13 & 12 & 2 & 2 & 2 \\
\hline Crude protein & 4 & 18 & 20 & 12 & 12 & 11 \\
\hline Crude fat & 1 & 4 & 6 & 4 & 2 & 2 \\
\hline NDF & 80 & 16 & 26 & 31 & 11 & 15 \\
\hline ADF & 52 & 9 & 13 & 14 & 3 & 5 \\
\hline Crude fibre & 45 & 6 & 11 & 11 & 3 & 5 \\
\hline Lignin & 7 & 2 & 2 & 3 & 1 & 1 \\
\hline
\end{tabular}


shown in Figure 1. The upward pointing green needles (|) represent the amplitude value of individually recorded JM and the downwards pointing blue needles (|) represent the time interval (s) between JM. The basic chewing rate $(\mathrm{JM} / \mathrm{min})$, the effective chewing rate $(\mathrm{JM} / \mathrm{min} / \mathrm{cycle})$ and regularity of $\mathrm{JM}$ are represented on the right vertical $y$-axis. The time interval between JM (s) is read on the left vertical y-axis.

It was visually observed that the whole barley meal begins at $10.00 \mathrm{am}$ and finishes at $10.09 \mathrm{am}$; thereafter the horse is licking the feed bucket until 10.11 am (Figure 1). The whole barley meal was visually observed to be eaten without any breaks and at a constant chewing rate. The visual observations of eating behaviour are supported by regular and con- of NDF in oats. In general the horses have a slower approach to ground grain and in particularly ground oats, which has a soft and dusty appearance (personal observations). No significant effect of grain processing on eating time, number of JM or basic chewing time is recorded but JM regularity is affected. Whole grain is systematically $(P<0.01)$ eaten more regular than rolled and ground grain, which results in a lower SPDDT value for whole grain. No overall model effect of day or meal is measured and no interaction between grain type and processing is measured and therefore not included in Table 4.

Visual observations of eating time and recorded efficient chewing time of individual grain types and processing for Standardbred horses and Icelandic horses are listed in Table 5.
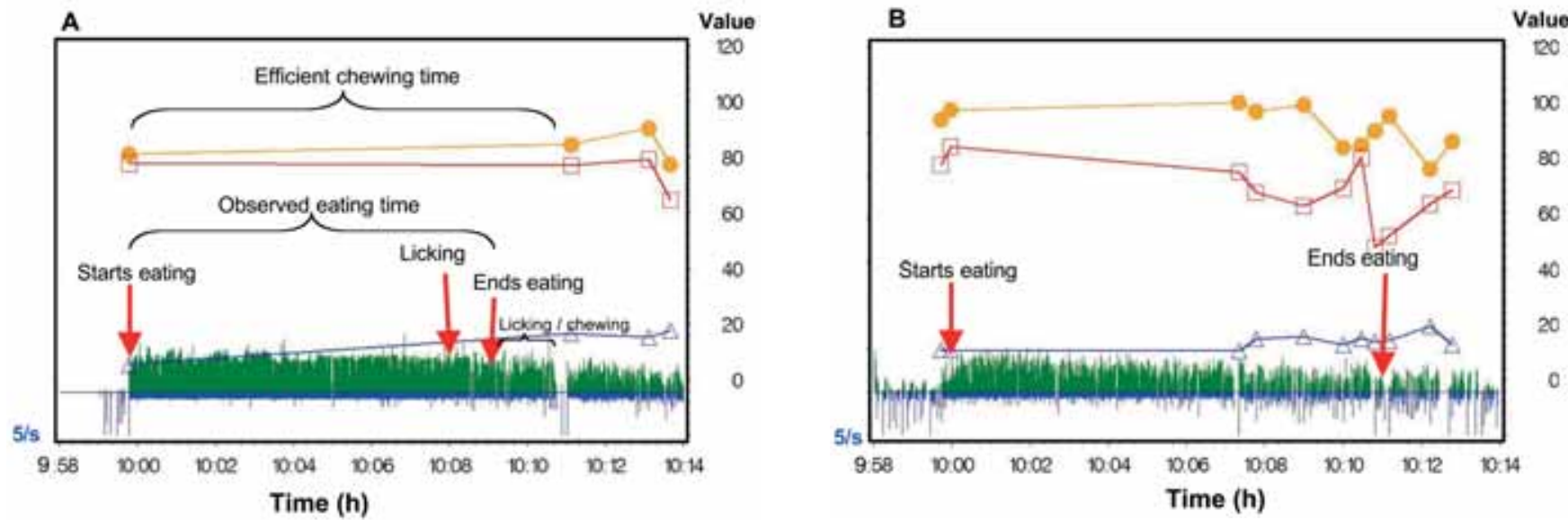

Fig 1 Jaw movement pattern of horse no. 104 before, during and after eating whole barley (A) and ground oat (B). The upward pointing green needles (|) represent the individually recorded JM and the downwards pointing blue needles (|) represent the time interval (s) between JM. The $x$-axis is time (h). The vertical left $y$-axis represents the scale for recorded basic chewing rate (PBCR, JM/min/cycle - $-0-$ ), the effective chewing rate (PECR, JM/min $\square \square$ ) and chewing regularity (SPDDT*100, $\triangle \triangle$ ).

Kieferschläge vor, während und nach dem Fressen des Pferds 104 von ganzer Gerste (A) und gemahlenem Hafer (B). Die aufwärts zeigenden grünen Nadeln (|) sind individuelle Kieferlagen und die abwärts zeigenden blaven Nadeln (|) sind die Zeitintervalle zwischen den Kieferlagen. Die Standardkaufrequenz (PBCR, JM/min/cyklus -O-), die effektive Kaufrequenz (PECR, JM/min $\square \square)$ und die Gleichmäßigkeit des JM $\left(\operatorname{SPDDT}^{*} 100, \triangle \triangle\right)$.

stant time intervals between JM (blue needles) of 0.7 s each. This results in low SPDDT values and represents a regular JM and chewing activity. The horse was visually observed to pause and chew the 11 min long ground oat meal irregularly and with many pauses. The recorded time interval between $J M$ varies from 1-5 s each. Despite different JM patterns of the two meals ( $A$ and $B$ ), the basic chewing rate value fluctuates around $90 \mathrm{JM} /$ min during both meals. The longer time interval between JM within each eating cycle lowered the effective chewing rate of ground oats (B), see Figure 1 .

The equipment and visual observations in the present experiment provide detailed information on chewing activity usable for further interpreting eating behaviour of horses. The Lsmean \pm SEM and P-values of recorded basic chewing rate, regularity of $J M$, number of $J M$ and efficient chewing time is listed in Table 4. In the present experiment horses spent 15 to $22 \mathrm{~min}$ eating one $\mathrm{kg}$ DM grain and Standardbred horses perform significantly fewer chews $(P=0.02)$ and spent shorter time eating $(P<0.01)$ as compared to Icelandic horses. The basic chewing rate and chewing regularity do not differ significantly between horse breeds. The horses use significantly $(P=0.03) 17 \%$ longer time and $17 \%$ more JM when eating oats as compared to wheat; however, it was not proportional with the higher content
Additionally Table 5 includes the chewing time values corrected to an average body weight of $500 \mathrm{~kg}$. Consequently, no systematic difference $(P<0.9)$ in efficient chewing time and number of JM $(P<0.8)$ was found between horse breeds after correcting the body weight.

In the present experiment the mean efficient chewing time for commercial concentrate range between 14-19 min per $\mathrm{kg}$ DM for the two groups of horses. No systematic difference between the two feeds was measured and therefore no effect of the physical form on eating time was found in the present experiment. The regularity of JM and basic chewing rate do not differ between commercial feed products.

The saliva secretion was visually observed immediately after beginning of a meal as a thick white foam on the lips and only observed for whole oats; however, the saliva secreted when eating muesli appeared as a waterish transparent secrete.

The size characteristics of washed faecal particles do not differ significantly between groups of horses (Table 6). Five \% of the washed faeces particles are retained on the top sieve with a pore size of $2.56 \mathrm{~mm}$, and the image analysis showed that $5 \%$ of the washed particles are longer than $12 \mathrm{~mm}$ (Table 6). 
The arithmetic mean particle length and width is found to be around $5 \mathrm{~mm}$ and $0.7 \mathrm{~mm}$ respectively. Both the sieving proportions and the washed faecal particles appear to be skewed to the left, with many small particles and few large particles (Table 6).

The accumulated distribution of faecal particle length is shown for the two groups of horses, where the bright line represents the Standardbred horses and the dark line represents the Icel- andic horses. See Figure 2. The accumulated distribution of length of faecal particles from both groups follows the same pattern; however, the particles from the Icelandic horses appear to include fewer short particles compared to Standardbred horses. Based on the results of the sieving technique between $44-45 \%$ of the particles are retained on sieves with a pore size of $0.5 \mathrm{~mm}$. Between $5-7 \%$ of the washed particles are retained on top sieves with a pore size of $2.56 \mathrm{~mm}$.

Table 4 The effect of grain type and processing on chewing activity in horses (Lsmean \pm SEM and P-value). Die Wirkung der Kornart und Aufbereitung auf die Kauaktivität der Pferde (Lsmeans \pm SEM and P-value).

\begin{tabular}{|c|c|c|c|c|c|c|c|c|c|c|c|}
\hline \multirow[b]{2}{*}{ Item } & \multicolumn{3}{|c|}{ Group } & \multicolumn{4}{|c|}{ Grain type } & \multicolumn{4}{|c|}{ Physical form } \\
\hline & I & $\|$ & SEM & Oat & Barley & Wheat & SEM & Whole & Rolled & Ground & SEM \\
\hline $\begin{array}{l}\text { Number of } \\
\text { JM }\end{array}$ & 1.17 & 1.68 & 0.14 & $1.58^{a}$ & $1.43^{\mathrm{b}}$ & $1.35^{\mathrm{b}}$ & 0.12 & 1.38 & 1.45 & 1.44 & 0.12 \\
\hline$P$-value & & & 0.02 & & & & 0.03 & & & & NS \\
\hline $\begin{array}{l}\text { Efficient } \\
\text { eating time }\end{array}$ & 15 & 22 & 1.60 & $21^{e}$ & $18^{f}$ & $18^{\mathrm{ef}}$ & 1.40 & 18 & 18 & 20 & 1.4 \\
\hline$P$-value & & & $<0.01$ & & & & NS & & & & NS \\
\hline $\begin{array}{l}\text { Basic } \\
\text { chewing rate }\end{array}$ & 1.54 & 1.54 & 0.04 & 1.54 & 1.53 & 1.54 & 0.03 & 1.53 & 1.56 & 1.53 & 0.03 \\
\hline$P$-value & & & NS & & & & NS & & & & NS \\
\hline $\begin{array}{l}\text { Regularity of } \\
J M\end{array}$ & 0.091 & 0.092 & 0.004 & $0.087^{c}$ & $0.087^{c}$ & $0.100^{d}$ & 0.004 & $0.068^{9}$ & $0.093^{h}$ & $0.111^{i}$ & 0.004 \\
\hline$P$-value & & & NS & & & & NS & & & & $<0.01$ \\
\hline
\end{tabular}

Number of JM (JM/g DM); Efficient chewing time (EPTIME, min/kg DM); Regularity of JM (SPDDT); Basic chewing rate (PBCR, JM / min); Group: Standard bred vs. Icelandic horses. Items within a row having different superscripts are significantly different; NS: not significant.

Table 5 The observed eating time, efficient chewing time and number of JM for individual feeds measured in Group I, Group II and after correcting to an average weight of $500 \mathrm{~kg}$ (Lsmean \pm SEM).

Beobachtete Fresszeit, effektive Kauzeit und Zahl von JM bei individuellen Fütterungen der Gruppe I, Gruppe II und nach der Berichtigung auf $500 \mathrm{~kg}$ (Lsmeans \pm SEM).

\begin{tabular}{|c|c|c|c|c|c|c|c|c|c|}
\hline \multirow[b]{2}{*}{ Feeds } & \multicolumn{3}{|c|}{ Standardbred horses } & \multicolumn{3}{|c|}{ Icelandic horses } & \multicolumn{3}{|c|}{ Corrected to $500 \mathrm{~kg}$ horses } \\
\hline & $\begin{array}{l}\text { Obs., min / } \\
\text { kg DM }\end{array}$ & $\begin{array}{l}\text { EPTIME, } \\
\min / \mathrm{kg} \\
\text { DM }\end{array}$ & $\mathrm{JM} / \mathrm{g} \mathrm{DM}$ & $\begin{array}{l}\text { Obs., min / } \\
\text { kg DM }\end{array}$ & $\begin{array}{l}\text { EPTIME, } \\
\min / \mathrm{kg} \\
\text { DM }\end{array}$ & $\mathrm{JM} / \mathrm{g} \mathrm{DM}$ & $\begin{array}{l}\text { Obs., min / } \\
\text { kg DM }\end{array}$ & $\begin{array}{l}\text { EPTIME, } \\
\min / \mathrm{kg} \\
\text { DM }\end{array}$ & $\mathrm{JM} / \mathrm{g} D M$ \\
\hline \multicolumn{10}{|l|}{ Oats } \\
\hline - whole & $15 \pm 2.7$ & $22 \pm 2.7$ & $1.57 \pm 0.2$ & $16 \pm 1.2$ & $22 \pm 2.2$ & $1.71 \pm 0.2$ & $14 \pm 1.1$ & $19 \pm 1.6$ & $1.46 \pm 0.12$ \\
\hline - rolled & $12 \pm 0.9$ & $13 \pm 2.7$ & $1.00 \pm 0.2$ & $16 \pm 1.2$ & $25 \pm 2.2$ & $2.04 \pm 0.2$ & $13 \pm 0.4$ & $16 \pm 1.6$ & $1.29 \pm 0.12$ \\
\hline - ground & $14 \pm 0.5$ & $15 \pm 3.3$ & $1.13 \pm 0.2$ & $22 \pm 2.9$ & $26 \pm 2.2$ & $1.92 \pm 0.2$ & $16 \pm 0.4$ & $18 \pm 1.8$ & $1.31 \pm 0.14$ \\
\hline \multicolumn{10}{|l|}{ Wheat } \\
\hline - whole & $12 \pm 2.2$ & $17 \pm 2.7$ & $1.32 \pm 0.2$ & $12 \pm 0.6$ & $17 \pm 2.2$ & $1.35 \pm 0.2$ & $11 \pm 1.1$ & $15 \pm 1.6$ & $1.20 \pm 0.12$ \\
\hline - rolled & $11 \pm 0.5$ & $14 \pm 3.3$ & $1.08 \pm 0.2$ & $18 \pm 1.7$ & $24 \pm 2.2$ & $1.79 \pm 0.2$ & $13 \pm 0.4$ & $16 \pm 1.8$ & $1.23 \pm 0.14$ \\
\hline - ground & $19 \pm 5.8$ & $9 \pm 3.3$ & $0.70 \pm 0.2$ & $18 \pm 1.2$ & $23 \pm 2.2$ & $1.69 \pm 0.2$ & $17 \pm 1.8$ & $13 \pm 1.8$ & $0.99 \pm 0.14$ \\
\hline \multicolumn{10}{|l|}{ Barley } \\
\hline - whole & $9 \pm 0.5$ & $12 \pm 2.7$ & $0.90 \pm 0.2$ & $13 \pm 1.2$ & $21 \pm 2.2$ & $1.61 \pm 0.2$ & $10 \pm 0$ & $14 \pm 1.6$ & $1.07 \pm 0.12$ \\
\hline - rolled & $20 \pm 7.6$ & $15 \pm 2.7$ & $1.17 \pm 0.2$ & $15 \pm 1.2$ & $18 \pm 2.2$ & $1.44 \pm 0.2$ & $16 \pm 2.5$ & $15 \pm 1.6$ & $1.16 \pm 0.12$ \\
\hline - ground & $14 \pm 1.8$ & $19 \pm 2.7$ & $1.44 \pm 0.2$ & $19 \pm 1.2$ & $22 \pm 2.2$ & $1.60 \pm 0.2$ & $15 \pm 0.4$ & $18 \pm 1.6$ & $1.35 \pm 0.12$ \\
\hline \multicolumn{10}{|c|}{ Commercial } \\
\hline - muesli & $9 \pm 1.3$ & $16 \pm 1.9$ & $1.29 \pm 0.2$ & $11 \pm 1.2$ & $16 \pm 1.6$ & $1.28 \pm 0.1$ & $9 \pm 0.4$ & $15 \pm 1.2$ & $1.16 \pm 0.10$ \\
\hline - feed pills & $10 \pm 1.3$ & $14 \pm 1.9$ & $1.17 \pm 0.2$ & $12 \pm 1.2$ & $19 \pm 1.6$ & $1.50 \pm 0.1$ & $10 \pm 0.4$ & $15 \pm 1.2$ & $1.18 \pm 0.10$ \\
\hline
\end{tabular}

Group I: $\mathrm{n}=3$, Group II: $\mathrm{n}=5$; Obs.: Observed eating time; EPTIME: Efficient chewing time; JM: jaw movements. 
Table 6 The size characteristics of washed faecal particle measured by sieving technique and image analysis (Lsmean \pm SEM). Die Größenverhältnisse der Kotpartikel bei der Anwendung der Siebtechnik und der Bildanalyse (Lsmean \pm SEM).

\begin{tabular}{|c|c|c|c|c|}
\hline Method & Items & Standardbred & Icelandic horses & $P$-value \\
\hline \multirow{5}{*}{$\begin{array}{l}\text { Proportion of particles } \\
\text { retained on screens of } \\
\text { different pore size }\end{array}$} & Observations & 3 & 5 & Groups \\
\hline & $2.56 \mathrm{~mm}$ pore size, $\%$ & $6 \pm 5$ & $5 \pm 2$ & NS \\
\hline & $1.00 \mathrm{~mm}$ pore size, $\%$ & $37 \pm 3$ & $39 \pm 4$ & NS \\
\hline & $0.50 \mathrm{~mm}$ pore size, $\%$ & $45 \pm 5$ & $44 \pm 3$ & NS \\
\hline & Bottom, \% & $11 \pm 4$ & $12 \pm 4$ & NS \\
\hline \multirow{5}{*}{ Image analysis } & Particle length & & & \\
\hline & - $95 \%$ percentile, mm & $11.5 \pm 0.8$ & $12.7 \pm 1.4$ & NS \\
\hline & - median, mm & $3.7 \pm 0.2$ & $4.0 \pm 0.4$ & NS \\
\hline & - APL, mm & $4.6 \pm 0.3$ & $5.1 \pm 0.5$ & NS \\
\hline & - APW, mm & $0.7 \pm 0.04$ & $0.7 \pm 0.07$ & NS \\
\hline
\end{tabular}

APL: arithmetic particle length; APW: arithmetic particle width; NS: not significant.

Results from the complete collection of faeces and recovery of apparently whole barley grain from Icelandic horses in Group II are listed in Table 7. The obtained results indicate that Icelandic horses excrete roughly $3 \%$ of the total number of ingested whole barley grains. The recovered whole barley grains appeared smaller and the mean weight per grain was 54\% smaller as compared to whole barley grains fed.

\section{Discussion}

Chewing and ruminating activity in ruminants depends on booth animal characteristics and intake of effective fibre, where the intake of NDF and feed particle size is a major dietary factor affecting chewing time (Mertens 1997). The results of the present experiment did not support the presumed hypothesis. Although the efficient chewing time for oats was systematically longer as compared to wheat, it was not proportional with the higher NDF content. This corresponds with Dulphy et al. (1997) who reported that neither NDF nor crude fibre content of various forages affects the voluntary dry matter intake in horses. NDF is a chemical feed characteristic and

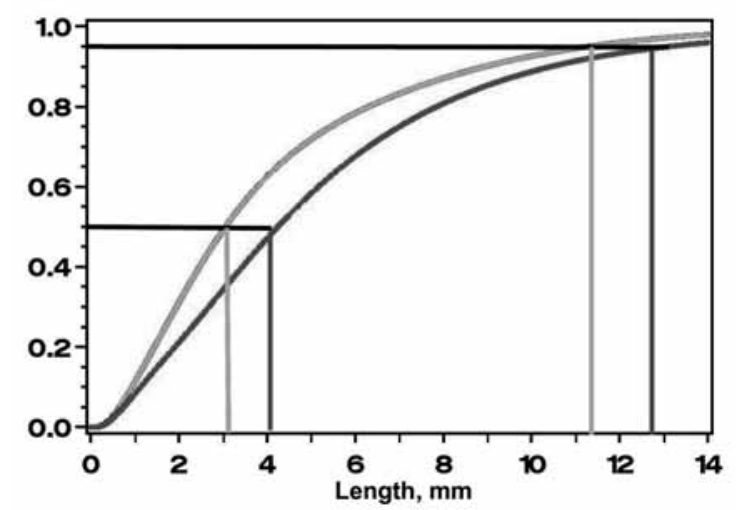

Fig 2 Accumulated distribution of particle length of washed faecal particles from Standardbred horses (bright curve) and Icelandic horses (dark curve) including indication of the median and $95 \%$ percentile values.

Verteilung der Kotpartikellänge bei Traberpferden (helle Kurve) und Islandpferden (dunkle Kurve) einschliesslich markierten Mittelwerten und $95 \%$ Werten. therefore, the effect of oats on increased efficient chewing time is due to other grain characteristics such as the physical form. Oats contain 3 times as much lignin as compared to wheat, which characterise the hard and sharp surface of whole oats (Vervuert et al. 2003, McDonald et al. 1998). Oats therefore require greater force to break (Van Soest 1994), which could explain the significantly greater number of jaw movements for oats. Meyer et al., (1975) and Brüssow et al. (2005) reported that 450-560 kg horses eat $1 \mathrm{~kg}$ whole oats in $9.7 \mathrm{~min}$ and $9.6 \mathrm{~min}$ respectively; however, accounting for variation between horses and dry matter content in oats in the present experiment, the eating time values for oats appear to be within the same range in all three experiments. Observed mean eating time for individual meals is generally shorter than the recorded mean efficient chewing time. See Table 5. Beginning and ending of the efficient chewing time depends on clustering JM into eating cycles. This might not correspond exactly to the visual observation of eating behaviour. Visual observation of eating time begins when feed is fed and ends when the fed bucket is empty. As illustrated in Figure 1 (A) the horse continues to lick and chew after the feed bucket is empty, which is included in an eating cycle.

Table 7 Estimated number of whole barley fed to Icelandic horses and recovered in faeces.

Angegebene Menge von Futter aus ganzer Gerste und enthaltener Mist bei Islandpferden.

\begin{tabular}{lc}
\hline Item & Icelandic horses \\
\hline $\begin{array}{l}\text { Observations } \\
\text { Estimated number of whole barley fed }\end{array}$ & 5 \\
$\begin{array}{l}\text { Mean weight of whole barley fed } \\
\text { (g DM/grain) }\end{array}$ & 9158 \\
Number of whole barley recovered in faeces & $0.0486 \pm 0.008$ \\
Mean weight of whole barley recov. \\
(g DM/grain) \\
$\begin{array}{l}\text { Proportion of whole barley excreted, \% of } \\
\text { DM }\end{array}$ \\
\hline${ }^{a}$ The total number of whole barley fed is calculated based on \\
the average weight of six barley grains and the weight of each \\
whole barley meal. \\
${ }^{b}$ Mean weight of six barley grains (g DM/grain).
\end{tabular}


Processing cereal grains did not decrease the eating time as hypothesised; therefore, the limit by which cereal grain size decrease eating time appears to be greater than $2 \mathrm{~mm}$ (screen size). An effective eating time value of $15 \mathrm{~min} / \mathrm{kg}$ DM ground oats was observed in the present experiment for Standardbred horses, whereas Meyer et al. (1975) observed a total eating time of $22.5 \mathrm{~min} / \mathrm{kg}$ ground oats. The number of JM per g DM did not differ systematically between processing. See Table 4. Therefore, the recorded longer efficient chewing time for processed grain might be due to longer time intervals between jaw movements within cycles. See illustration in Figure 1. A low SPDDT value (Table 4) indicates regularity of JM, which could be used as a numerical value to qualify cereal grain characteristics and palatability. According to Houpt (1990) and Hawkes (1985) horses prefer oats to other grains. Based on the longer efficient chewing time for ground oats and irregular JM for ground grain the physical form seams to overrule the good taste of oats in Icelandic horses. This is in agreement with Meyer et al. (1975) who reported that eating time for ground oats decreased from 22.5 to $10 \mathrm{~min} / \mathrm{kg}$ feed when adding whole oats to ground oats $1: 1$. The decreased eating time is presumably due to the physical appearance of whole oats that provide a good grip and mechanically stimulate the saliva secretion. Other authors reported that palatability is important to horses (Hawkes 1985) and the physical form is more important than the feed energy content (Ralston 1984). Dixon (2000) hypothesised that increasing the chewing time could help diminishing the development of dental overgrowth by increasing the attrition of the cheek teeth. According to the results in the present experiment horses spent longer time eating ground grain. However, it is questionable and could not be detected with the used experimental method, weather the mastication stroke is the same for ground grain as compared to whole grain.

When all the horses were eating whole oats they produced white foamy saliva, which was not observed for processed grain. This observation could be explained by a strong mechanical stimulation of the oral mucosa by whole oat grains and therefore not observed for processed grain (Nørgaard 1995). Eckersall (1984) reported that bicarbonate is rapidly converted into carbon dioxide, which indicates that saliva secreted when eating whole oats contain bicarbonate. The ingredients of commercial muesli feed include $12 \%$ molasses and according to Meurman et al. (1987) sweet drinks in humans result in a chemical stimulation of saliva secretion. The content of bicarbonate in the two different appearing saliva secrets was not analyzed; therefore, it is uncertain if both chemical and physical stimulation of saliva secretion provide the same possible neutralising effect in the stomach.

The Icelandic horses spent significantly longer time eating (min/kg DM) the different meals as compared to Standardbred horses; however, the basic chewing rate did not differ systematically between the two groups of horses. When correcting the eating time values to the inverse body weight, no significant difference between groups of horses was measured. This indicates that the mean chewing time per $\mathrm{kg} D M$ is proportional to the inverse body mass in horses. The results correspond to findings by Shingu et al. (2001) who reported that chewing rate did not differ between $385 \mathrm{~kg}$ native Hokkaido horses and $536 \mathrm{~kg}$ light horses. The mean chewing time per $\mathrm{kg} D M$ is considered to be proportional to the inver- se body mass in dairy cows (Beauchemin 2003). The difference in horses could also be due to a greater bite size, cheek teeth surface or mastication stroke of Standardbred horses as suggested by Meyer et al. (1975).

Barley straw contributes to roughly $80 \%$ of the total daily intake of NDF based on the chemical analysis. Therefore, the majority of the retained washed faecal particles are considered to be undigested straw residue. Due to the experimental design the effect of individual grains and processing on faecal particle size distribution cannot be measured. The obtained results do not indicate differences in faecal particle size distribution between horse breeds. In the present experiment 44-45\% of the washed faeces particles are retained on the sieve with a pore size of 0.50-1.00 mm, which correspond to Meyer et al. (1975) who reported that $41 \%$ of faecal particles of a hard hay diet is retained on a screen with the pore size of 0.40-1.00 mm. The size characteristics of washed faecal particles in the present experiment did not differ between the horses despite their different body mass. This is in agreement with Shingu et al. (2001) who reported that the apparent digestibility of NDF, DM or crude protein is independent of body mass and breeds.

Approximately $3 \%$ of the estimated number of ingested whole barley grains appeared in faeces within 24 to 96 hours after ingestion but the mean weight of the recovered undigested grains had been reduced by $54 \%$. It was not determined weather the difference in weight was due to digestion of nutrients or difference in grain size measured before feeding and after recovery. The primary effect of processing cereal grains is generally considered to increase the overall digestibility (Vervuert et al. 2003); however, the results of the present experiment indicate that $97 \%$ for whole barley grains fed to horses is digested. The $3 \%$ excretion of whole grain represents a loss of nutrients available for horses. If the price of cold processing cereal grains exceeds the price of whole grain by $3 \%$; it is more faceable from an economical point of view to feed whole grains. Additionally preserving whole grain compared to processed grain is easier in order to avoid contamination and loss of nutrients (Hoseney 1994, Camire et al. 1990).

In conclusion the presumed hypothesis could not be accepted; however, processing cereal grain does affect chewing activity in horses. Ground grain stimulates horses to increased chewing time and irregularly chewing activity as compared to whole and rolled grain. Based on recorded chewing activity characteristics it appears that horses dislike ground grains. The regularity of chewing activity appears to provide a new biological method to study characteristics of processed cereal grains. The longer eating time per $\mathrm{kg} D M$ for ponies as compared to Standardbred horses can be explained by considering chewing time per $\mathrm{kg} \mathrm{DM}$ to be related to body size.

\section{Implications}

The obtained results appear to provide a new tool for horse feed manufacturers to test if horses like or dislike a feed product. Horses appear to prefer coarsely processed grains. Furthermore the total collection of faeces revealed that $97 \%$ of whole grains fed to horses are digested and therefore whole cereal grains make a god horse feed. 


\section{Literature}

Argo C. McG., J. E. Cox, C. Lockyer and Z. Fuller (2002): Adaptive changes in the appetite, growth and feeding behaviour of pony mares offered ad libitum access to a complete diet in either a pelleted or chaff-based form. Animal Science. 74, 517-528

Balch C. C. (1971): Proposal to use time spent chewing as an index of the extent to which diets for ruminants possess the physical property of fibrousness characteristic of roughages. British Journal of Nutrition. 26, 383-392

Beauchemin K. A., W. Z. Yang and L. M. Rode (2003): Effects of particle size of alfalfa-based dairy cow diets on chewing activity, ruminal fermentation, and milk production. J. Dairy Sci. 86, 630-643

Camire M. E., A. Camire and K. Krumhar (1990): Chemical and nutritional changes in foods during extrusion. Food science and nutrition 29, 35-57

Dixon P. M. (2000): Satellite article. Removal of equine dental overgrowths. Equine vet. Educ. 12, 68-81

Dulphy J. P., W. Martin-Rosset, H. Dubroeucq, J. M. Ballet, A. Detour and M. Jailler (1997): Compared feeding patterns in ad libitum intake of dry forages by horses and sheep. Livestock Production Science. 52, 49-56

Eckersall P. D. (1984): Equine whole saliva: A sample collection system and biochemical analysis. Veterinary Record. 1 15, 437-438

Hawkes J., M. Hedges, P. Daniluk, H. F. Hintz and H. F. Schryver (1985): Feed preferences of ponies. Equine vet. J. 17, 20-22

Heleski C. R., A. C. Shelle, B. D. Nielsen and A. J. Zanella (2002): Influence of housing on weanling horse behavior and subsequent welfare. Applied Animal Behaviour Science 78, 291-302

Hoseney R. C. (1994): Principles of cereal science and technology. 2. edition. American Association of Cereal Chemists, Inc. St. Paul, Minnesota, USA. 125-146

Houpt K. A. (1990): Ingestive Behavior. Veterinary Clinics of North America: Equine Practice. 6, 319-337

Kristensen V. F. and P. Nørgaard (1987): Effect of roughages quality and physical structure of the diet on feed intake and milk yield of the dairy cow. Cattle Production Research. 79-91

NRC (1989): Nutrient requirements of horses, 5th ed. National Academy Press, Washington, D. C., USA.

Nørgaard P. and K. Hilden (2004): A new method for recording mastication during eating and ruminating in sheep. Journal of Animal and Feed Science. 13. Suppl. 1, 175-178

Nørgaard P. (2003): Tyggetid som mål for foderets fysiske struktur. In DJF Rapport, Kvægets ernæring og fysiologi. Part 1 - Næringsstofomsæining og fodervurdering. 489-509

Nørgaard P. (1995): Effect of short-chain fatty acids on salivary flow in ruminants. In Physiological and Clinical Aspects of Short-chain Fatty Acids. Ed. J. H. Cummings, J. L. Rombeau, T. Sakata. Cambridge University Press, England. 233-241
McDonald P., R. A. Edwards, J. F. D. Greenhalgh and C. A. Morgan (1998): Animal Nutrition, 5 ed. Addison Wesley Longman Limited, United Kingdom

Mertens D. R. (1994): Regulation of forage intake. In: Forage quality, evaluation, and utilization. Ed. G. C. Fahey, Jr. American Society of Agronomy, Inc, Crop Science Society Inc, Soil Science Society, Inc, Madison, Wisconsin, USA

Meurman J. H., I. Rytömaa, K. Kari, T. Laakso and H. Murtomaa (1987): Salivary $\mathrm{pH}$ and glucose after consuming various beverages, including sugar-containing drinks. Caries Res. 21, 353-359

Meyer H. (1995): Pferdefütterung. Blackwell Wissenschafts-Verlag, 3. Auflage, Austria

Meyer H., L. Ahlswede and H. J. Reinhardt (1975): Untersuchungen über Fressdauer, Kaufrequenz und Futterzerkleinerung beim Pferd. Dtsch. Tierärztl. Wschr. 82, 54-58

Pagan J. D., S. G. Jackson and S. E. Duren (1998): What does your horse weigh? In Advances in equine nutrition. Ed. J. D. Pagan. Nottingham University Press, England. 105-109

Raff L. and U. P. Jørgensen (2003): Tyggeaktivitet og partikelstørrelse i fæces hos travheste fodret med forskellige typer grovfoder. BS thesis, The Royal Veterinary and Agricultural University, Denmark

Ralston S. L. (1984): Controls of Feeding in Horses. Journal Animal Science. 59, 1354-1361

SAS Institute Inc. (1999): SAS/STAT User's Guide, Version 8, Cary, NC, USA.

Schleisner C., P. Nørgaard and H. H. Hansen (1999): Discriminant Analysis of Patterns of Jaw Movement During Rumination and Eating in a Cow. Acta Agric. Scand. Sect. A Animal Sci. 49, 251-259

Shingu Y., S. Kondo, H. Hata and M. Okubo (2001): Digestibility and number of bites and chews on hay at fixed level in hokkaido native horses and light half-bred horses. J. Equine Sci. 12, 145-147

Stoldt W. (1952): Vorlag zur Vereinheitlichung der Feetbestimmung in Lebensmitteln. Fette und Seifen. 52, 206-207

Van Soest P. J. (1994): Nutritional Ecology of the Ruminant. 2 ed. Comstock Publishing Associates a division of Cornell University Press, Ithaca, NY 14850, USA, 140-155

Vervuert I., M. Coenen and C. Bothe (2003): Effects of oat processing on the glycaemic and insulin responses in horses. J. Anim. Physiol. Anim. Nutr. 87, 96-104

Zeyner A., C. Geissler and A. Dittrich (2004): Effects of hey intake and feeding sequence on variables in faeces and faecal water (dry matter, $\mathrm{pH}$ value, organic acids, ammonia, buffering capacity) of horses. J. Anim. Physiol. Anim. Nutr. 88, 7-19

Dr. Christine Brøkner

KVL, Department of Basic Animal and Veterinary Sciences

Grønnegårdsvej 7

1870 Frederiksberg C, Denmark

christine@broekner.dk

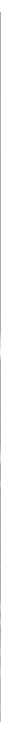

